Fish embryology

\title{
EFFECTS OF CONSTANT MAGNETIC FIELDS ON RESPIRATION OF RAINBOW TROUT (ONCORHYNCHUS MYKISS WALB.) EMBRYOS
}

\author{
WPEYW STAŁYCH PÓL MAGNETYCZNYCH NA ODDYCHANIE \\ ZARODKÓW PSTRĄGA TĘCZOWEGO \\ (ONCORHYNCHUS MYKISS WALB.)
}

Department of Anatomy and Embryology of Fish, Agricultural University of Szczecin, Poland

Oxygen uptake and carbon dioxide release by rainbow trout (Oncorhynchus mykiss Walb.) embryos exposed to constant magnetic fields of 5 and $10 \mathrm{mT}$ (oxygen uptake and carbon dioxide release) and 50, 150, and $300 \mathrm{mT}$ (oxygen uptake) were measured. The data were compared with those recorded in embryos developing under natural magnetic field (control).

The magnetic fields tested were found to stimulate respiratory processes in the rainbow trout embryos as shown by a significantly increased oxygen consumption, particularly during periods of intensified morphogenesis.

Exposure to 5 and $10 \mathrm{mT}$ magnetic fields resulted in a slightly higher carbon dioxide release, the oxygen consumption being observed to increase as well. The respiratory quotient of the embryos exposed to magnetic fields was slightly higher than that in the control.

\section{INTRODUCTION}

The last three decades have supplied a growing evidence that magnetic fields different from those of the natural Earth's background affect life processes of organisms, including fish, exposed to those fields (Tenforde 1979; Blank 1993). The effects are manifested as, i.a., acceleration or slow-down of some functions and are particularly pronounced in some locomotory functions. Our.earlier studies demonstrated, i.a., significant effects of magnetic field changes on the cardiac mu- 
scle performance in fish embryos and larvae, and on the performance of skeletal muscles operating the juvenile fish pectoral fins (Winnicki and Formicki 1990; Formicki 1992; Winnicki et al. 1993; Formicki and Winnicki 1996). Acting on the premises that all the locomotory responses rely on energy expenditure and that the energy can be mobilised by oxygen supplied from without (as evidenced by acceleration of heart beat rate resulting in intensified circulation and acceleration of pectoral fin respiratory beat rate), it was decided to measure the amount of oxygen taken up (and, in some cases, of carbon dioxide released) by rainbow trout (Oncorhynchus mykiss Walb.) embryos exposed to artificial constant magnetic fields and to compare the results with corresponding data obtained under the natural geomagnetic conditions. The question was addressed whether, and how, the respiration could be altered by application of a magnetic field. The tests were run in different fields in an attempt to determine relationships between field parameters and responses of a developing organism.

\section{MATERIAL AND METHODS}

The tests were carried out in 1994-1996 at the Department of Fish Anatomy and Embryology, Agricultural University of Szczecin on developing embryos of rainbow trout (Oncorhynchus mykiss Walb.)

Materials (i.e., rainbow trout eggs and sperm), obtained from spawners kept at fish farms in Miastko and Żelkowo (District of Słupsk), were transported to the laboratory where insemination (dry) and fertilisation were effected. Subsequently, the hydrated eggs were distributed for incubation on Petri dishes filled with water to $6 \mathrm{~mm}$ height. Those "mini-incubators" were kept throughout the period of the development either in an insulated room or in a special water mantle (laboratory hatchery), whereby the constant temperature of $10^{\circ} \mathrm{C} \pm 1^{\circ} \mathrm{C}$ was maintained.

Respiration of the embryos was measured at 6 stages of the embryonic development, a particular attention being paid to the following stages of intensified morphogenesis:

- early gastrulation (development of blastoderm and periblast, formation of the gastrula, division into three embryonic layers, beginning of blastopore closure): $60-80 \mathrm{D}^{\circ}$;

- prior to blastopore closure (formation of the primordial neural disc and notochord, termination of epiboly, blastopore closure): $90-100 \mathrm{D}^{\circ}$;

- post-blastopore closure (separation of optical cups, formation of 5 neuromeres, appearance of gill arches): $110-130 \mathrm{D}^{\circ}$;

- neural tube development into brain and vertebral cord, kidney, and a part of gonads; onset of regular heart beat: $140-150 \mathrm{D}^{\circ}$;

- appearance of eyes and further development of circulatory system (appearance of pigment in eyes, development of circulatory system, further development of gonads): $160-200 \mathrm{D}^{\circ}$; 
- active embryo phase (pre-hatch embryo, onset of opercular movements): 210-290 D (Vernier 1967; Opuszyński 1979; Klinkhardt et al. 1987; Depeche and Billard 1994).

The $\mathrm{O}_{2}$ uptake and $\mathrm{CO}_{2}$ release by the developing embryos were measured either with the Winkler technique $\left(\mathrm{O}_{2}\right.$ uptake) in flow-through respirometers, or with the modified Warburg manometric technique $\left(\mathrm{O}_{2}\right.$ uptake and $\mathrm{CO}_{2}$ release).

In the first case, the eggs were transferred to $13.5 \mathrm{~mm}$ diameter, $140 \mathrm{~mm}$ long cylindrical flow-through plexiglass chambers, one placed between the poles of the magnetic field source and the other away from it. The water oxygen content was determined with the Winkler technique as described in "Physical and chemical methods for water and wastewater analyses" (Hermanowicz et al. 1976). The $\mathrm{O}_{2}$ uptake was determined as a difference between oxygen contents in the chamber's inlet and outlet. A single test took $240 \mathrm{~min}$. during which time 6 measurements were taken. Water temperature was maintained constant by keeping the test chambers in additional buffering containers to make sure that identical thermal conditions were prevailing in the magnetic field, control, and in the Mariott bottle. Although allowing to remove metabolic products from the test chamber and ensuring stability of gas components in the incoming water, the flow-through technique is of low sensitivity. It was used to determine the differences in oxygen consumption between the control and treatment embryos exposed to magnetic fields of a relatively high inductances $(50,150$, and $300 \mathrm{mT})$ as more conspicuous responses in those fields were anticipated.

To ensure a high sensitivity, the Warburg apparatus manometers were used in weaker fields ( 5 and $10 \mathrm{mT}$ ). The duration of the test was shortened to reduce effects of changes in gas ratio in the measuring cell which occur during the test and distort the results. A single test took 90 min. during which the manometer column height was read at 15-min. intervals. As the eggs of salmonids (including those of the rainbow trout) are at some stages of their development particularly prone to mechanical damage and sensitive to vibrations (Privolnev and Razumovskij 1939; Vernier 1967; Winnicki 1967; Opuszyński 1979), it was decided against using a shaker in order to prevent additional stress to or deaths of embryos, which would lead to distortion of data.

Constant magnetic fields were produced by a computer-controlled magnetic field generator for embryo-physiological tests, manufactured at the Institute of Telecommunications and Acoustics, Wrocław Technical University (Duchiewicz and Formicki 1994) and by an electromagnet.

A total of 5 series of tests were run. In 1995, $\mathrm{O}_{2}$ uptake by the rainbow trout embryos exposed to 50,150, and $300 \mathrm{mT}$ magnetic fields was measured at various stages of embryonic development, from $60 \mathrm{D}^{\circ}$ to hatch. The fields were generated with 
the electromagnet in order to produce stronger fields. In 1996, the embryos' responses to 5 and $10 \mathrm{mT}$ fields at the same developmental stages were recorded. The fields were generated with the computer-controlled apparatus mentioned above, allowing a precise control and fine tuning of the weak field. An HTM hallotronic teslameter (manufactured by the Institute of Telecommunications and Acoustics, Wrocław Technical University) was used to measure and control field inductance.

Differences between treatments and the control were tested for significance with Student's t test applied with the use of Statgraphics ${ }^{\circledR}$ v. 6.0 Manugistics ${ }^{\mathrm{TM}}$ statistical package.

\section{RESULTS}

$\mathrm{O}_{2}$ consumption in 50,150 , and $300 \mathrm{mT}$ magnetic fields

Table 1 summarises data on $\mathrm{O}_{2}$ consumption by the rainbow trout embryos exposed to 50,150, and $300 \mathrm{mT}$ fields and in the control. As shown by the data, the mean $\mathrm{O}_{2}$ uptakes in 50 and $150 \mathrm{mT}$ fields differed significantly from the control throughout the period of observations. Significant differences were found also to exist between all the treatments combined (pooled results in 50,150, and $300 \mathrm{mT}$ fields) and the control. Differences in $\mathrm{O}_{2}$ uptake, resulting from magnetic field effects, were observed in some stages of the embryonic development. In the 50 and $150 \mathrm{mT}$ fields, the $\mathrm{O}_{2}$ uptake clearly increased, relative to the control, within 160-200 $\mathrm{D}^{\circ}$ (appearance of eyes), an increase being also observed within $90-100 \mathrm{D}^{\circ}$ period (formation of primordial neural disc) in the 150 and $300 \mathrm{mT}$ fields. Additionally, differences in $\mathrm{O}_{2}$ uptake between the treatment and the control were also recorded within $60-80 \mathrm{D}^{\circ}$ (gastrulation) in the $50 \mathrm{mT}$ field, while in the $150 \mathrm{mT}$ field the differences occurred within 90-200 $\mathrm{D}^{\circ}$ (from blastopore closure to circulatory system formation). In none of the three field inductances tested were statistically significant treatment vs. control differences recorded for the 210-290 $\mathrm{D}^{\circ}$ stage (active embryo phase). A reversed trend (reduced treatment $\mathrm{O}_{2}$ uptake relative to the control) was observed in the 50 and $300 \mathrm{mT}$ fields within $140-150 \mathrm{D}^{\circ}$ (onset of cardiac activity).

$\mathrm{O}_{2}$ consumption in 5 and $10 \mathrm{mT}$ fields

Data on $\mathrm{O}_{2}$ consumption by the rainbow trout embryos exposed to 5 and $10 \mathrm{mT}$ constant magnetic fields and in the control are shown in Table 2. As those treatments involved the use of the Warburg apparatus manometers, differences in $\mathrm{O}_{2}$ consumption at various developmental stages, shown in Tables 1 and 2, may have resulted from different methodologies. This finding supports observations reported by Pattee (1962) who compared results obtained with different techniques and concluded that results obtained under identical conditions may differ considerably. Statistically significant differences between $\mathrm{O}_{2}$ consumption in magnetic field and in the control were recorded both for the mean uptake in both the $5 \mathrm{mT}$ ( 90 records, $\mathrm{p}=0.001$ ) and $10 \mathrm{mT}$ ( 85 records, $\mathrm{p}=0.036$ ) fields and for all the records combined ( 175 records, $\mathrm{p}=0.001$ ). Application of 5 and $10 \mathrm{mT}$ magnetic 
fields resulted in increased $\mathrm{O}_{2}$ uptake by the embryos within 60-80 $\mathrm{D}^{\circ}$ (onset of gastrulation), $110-130 \mathrm{D}^{\circ}$ (after blastopore closure), and 140-150 $\mathrm{D}^{\circ}$ (organogenesis), the differences relative to the control being highly significant (significance levels of 0.005 to 0.014). No reversal of the trend, i.e., reduced $\mathrm{O}_{2}$ uptake in a magnetic field, was recorded. Significant differences relative to the control were noted also in the $5 \mathrm{mT}$ field within 160-200 $\mathrm{D}^{\circ}$ (appearance of eyes). No significant differences compared to the control occurred within $90-100 \mathrm{D}^{\circ}$ (formation of primordial neural disc) and within 210-290 $\mathrm{D}^{\circ}$ (active embryo phase). In the $10 \mathrm{mT}$ field, no statistically significant differences with the control were recorded within 90-100, 160-200, and 210-290 D ${ }^{\circ}$.

(X 1E-3)

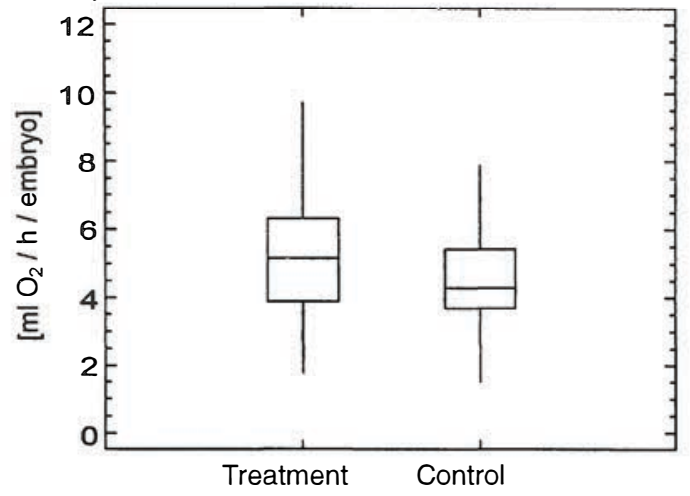

Fig. 1. Oxygen consumption by rainbow trout ( $\mathrm{On}$ corhynchus mykiss Walb.) embryos exposed to 50,150 , and $300 \mathrm{mT}$ magnetic fields and inthe control; all treatment observations pooled

$(X 1 E-3)$

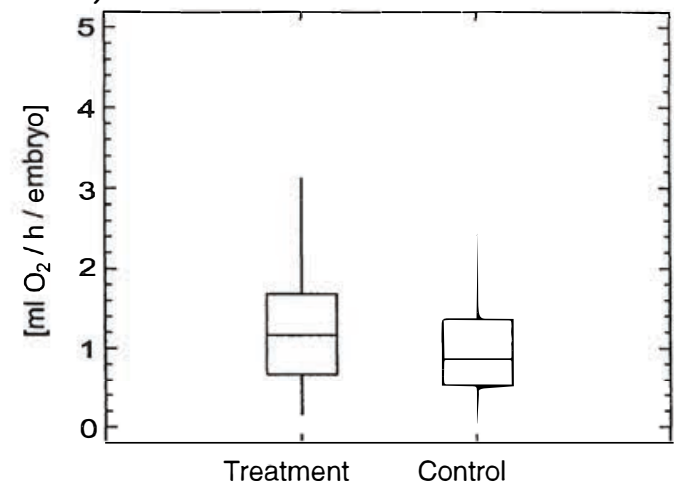

Fig. 2. Oxygen consumption by rainbow trout (Oncorhynchus mykiss Walb.) embryos exposed to 5 and $10 \mathrm{mT}$ magnetic fields and in the control; all treatment observations pooled
Noteworthy is the fact that none of the treatment magnetic field inductances $(5,10,50,150$, and $300 \mathrm{mT}$ ) produced statistically significant treatment vs. control differences prior to hatch, i.e., within 210-290 D (Tables 1 and 2).

In order to visualise differences in rainbow trout embryos' $\mathrm{O}_{2}$ uptake between the treatments and the control, box-and-whisker plots were prepared with data obtained in different field inductances and with combined data for the three high-inductance treatment (50, 150 , and $300 \mathrm{mT}$ ). The plots allow to analyse the distribution of data in the groups and to conclude that, generally, exposure to a magnetic field produces larger differences between $\mathrm{O}_{2}$ uptakes than does the control (as evidenced by larger areas covered by the horizontal lines reflecting the upper and lower quartiles). Both in high $(50,150$, and $300 \mathrm{mT}$; Fig. 1) and in low (5 and 10 mT; Fig. 2) inductance fields, the median $\mathrm{O}_{2}$ consumption lie above the medians for the control, the quartile ranges being clearly wider. 
Table 1

Oxygen consumption ( $\mathrm{ml} \mathrm{O}_{2} / \mathrm{h} / \mathrm{embryo}$ ) by rainbow trout (Oncorhynchus mykiss Walb.) embryos exposed to 50, 150, and $300 \mathrm{mT}$ magnetic fields and in the control

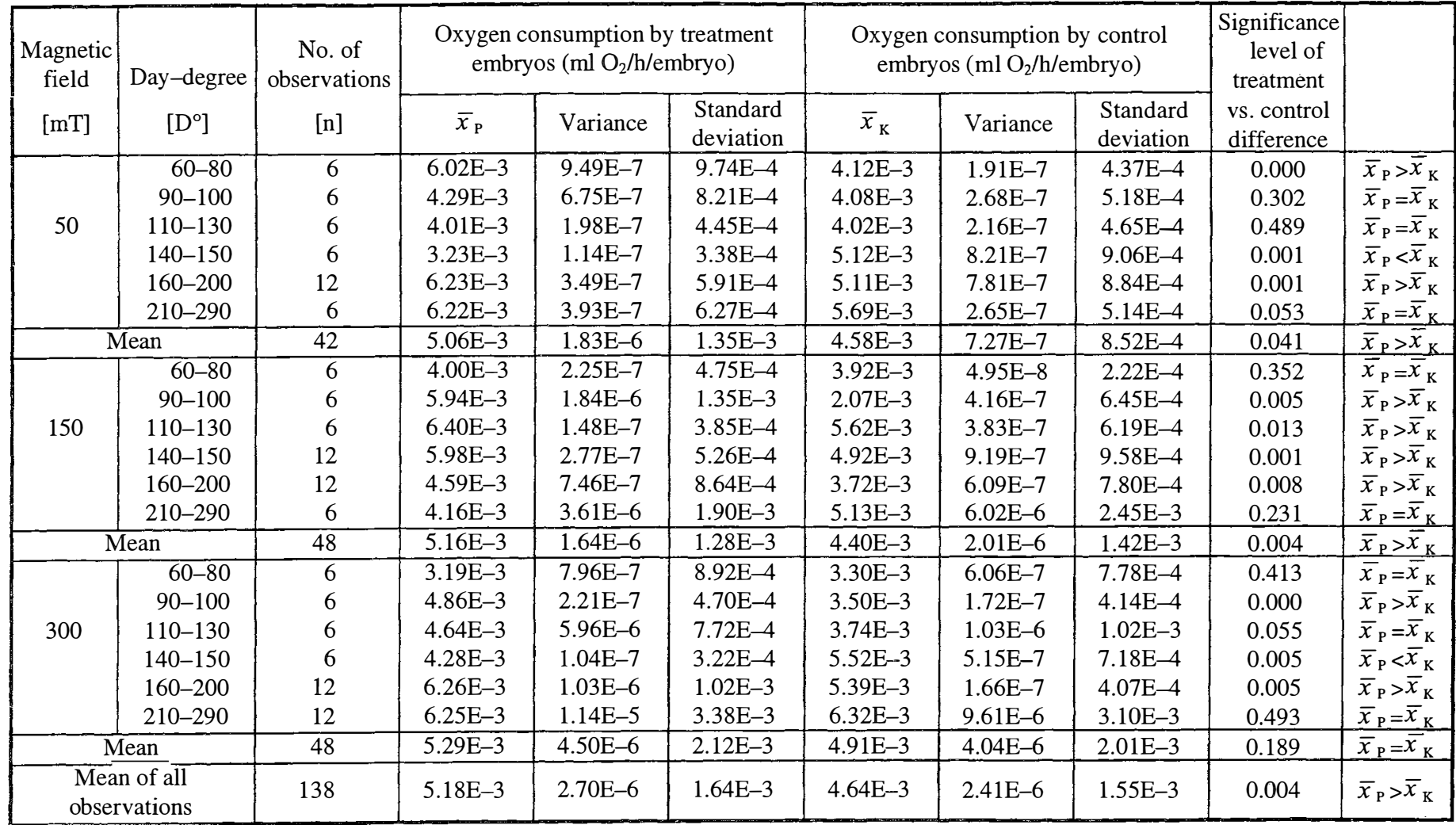

$\bar{x}_{\mathrm{P}}-$ mean oxygen consumption by treatment embryos; $\bar{x}_{\mathrm{K}}$-mean oxygen consumption by control embryos; Mean number of embryos observed per treatment was 100 . 
Table 2

Oxygen consumption ( $\mathrm{ml} \mathrm{O}_{2} / \mathrm{h} / \mathrm{embryo}$ ) by rainbow trout (Oncorhynchus mykiss Walb.) embryos exposed to 5 and $10 \mathrm{mT}$ magnetic fields and in the control

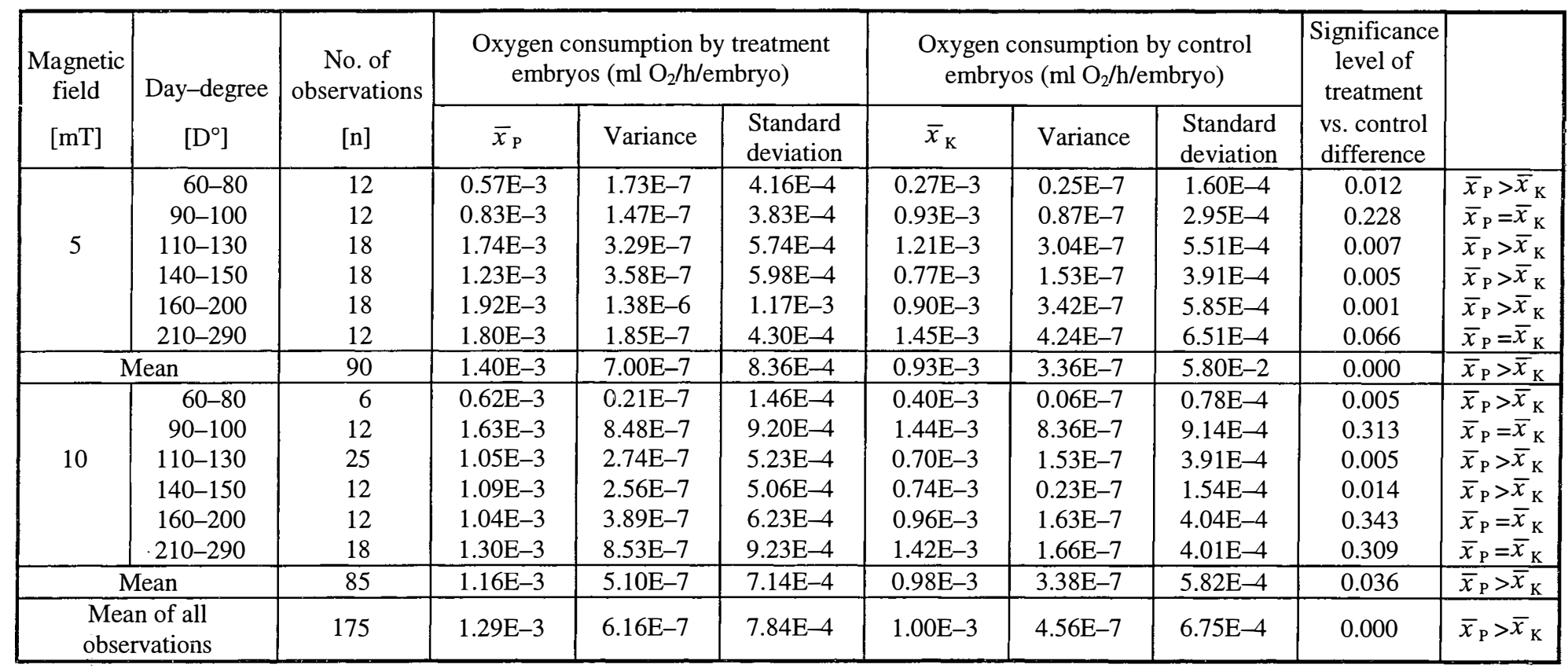

$\bar{x}_{\mathrm{P}}-$ mean oxygen consumption by treatment embryos; $\bar{x}_{\mathrm{K}}$-mean oxygen consumption by control embryos; Mean number of embryos observed per treatment was 35 . 


\section{Table 3}

Carbon dioxide release (ml CO2/h/embryo) by rainbow trout (Oncorhynchus mykiss Walb.) embryos exposed to 5 and $10 \mathrm{mT}$ magnetic fields and in the control

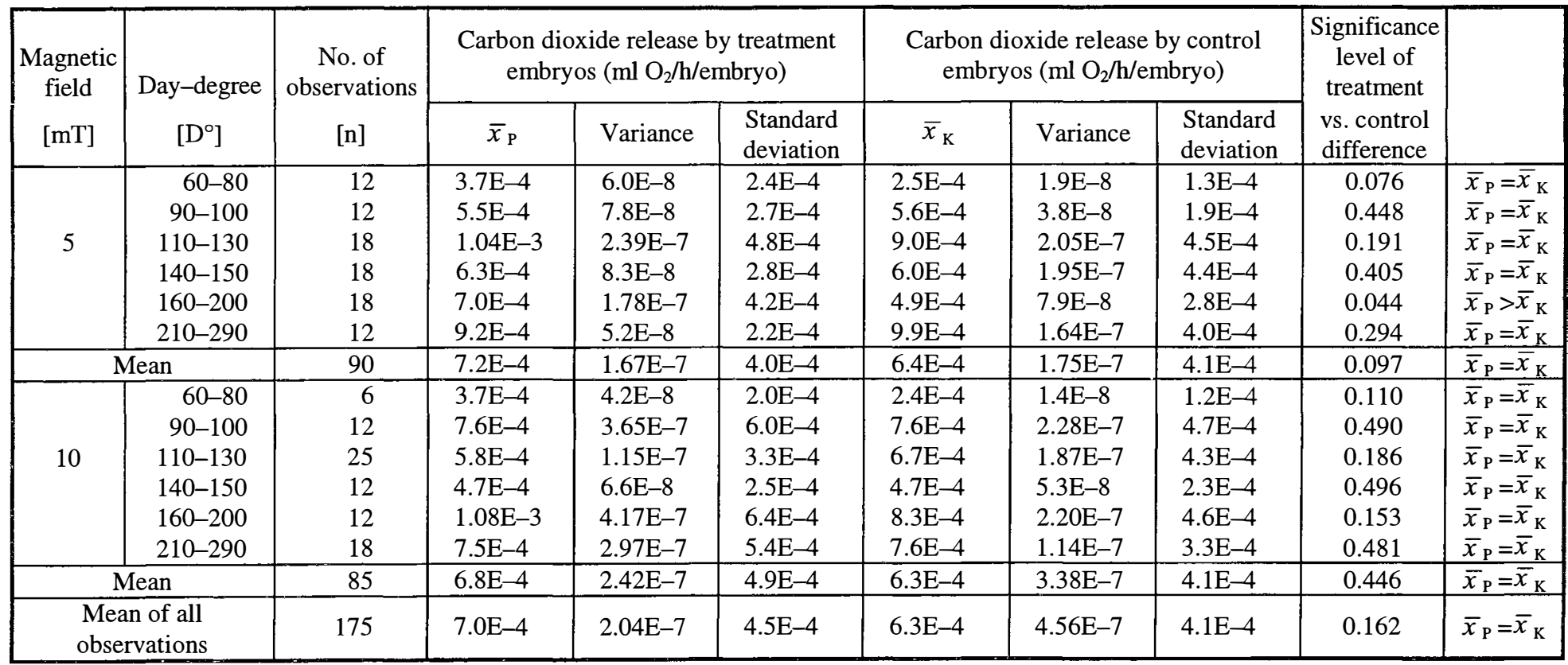

$\bar{x}_{\mathrm{P}}-$ mean carbon dioxide release by treatment embryos; $\bar{x}_{\mathrm{K}}-$ mean carbon dioxide release by control embryos; Mean number of embryos observed per treatment was 35 . 
(X 1E-3)

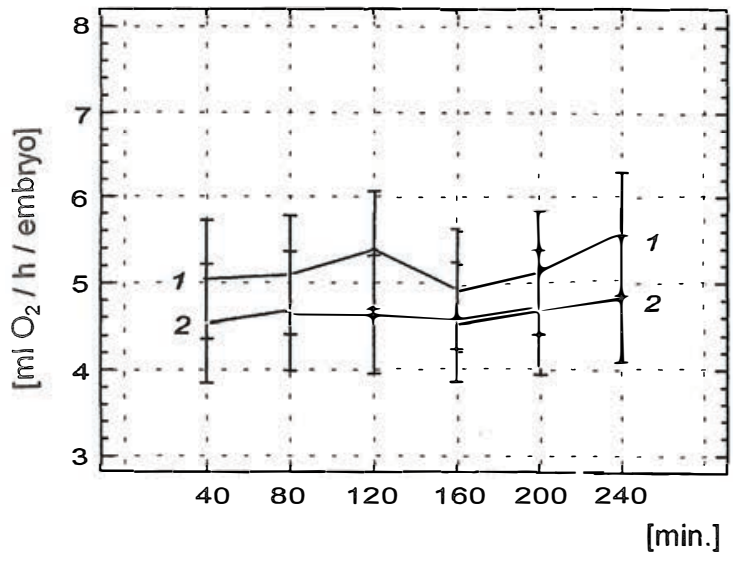

Fig. 3. Changes in oxygen consumption by rainbow trout (Oncorhynchus mykiss Walb.) embryos exposed to magnetic fields and in the control throughout the experiment; observations in 50,150, and $300 \mathrm{mT}$ fields pooled; $1-$ oxygen consumption in magnetic fields; 2 -xygen consumption in control

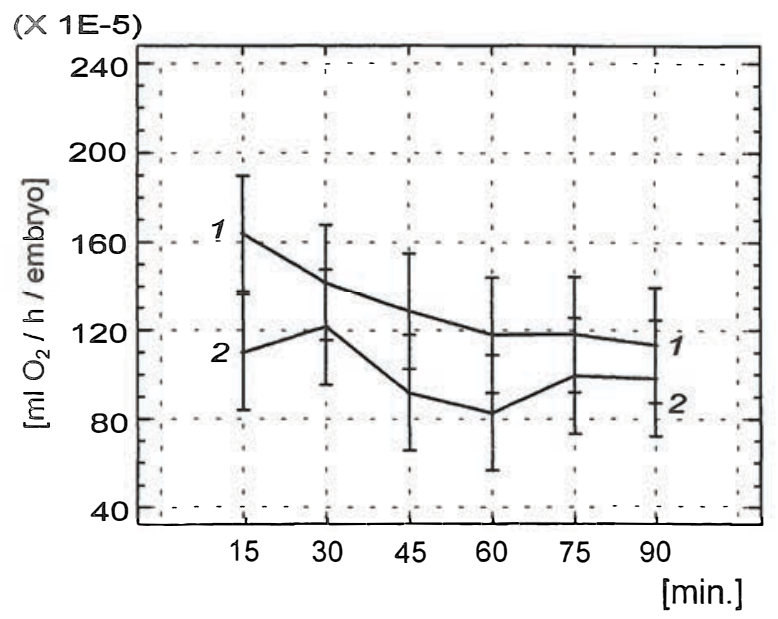

Fig. 4. Changes in oxygen consumption by rainbow trout (Oncorhynchus mykiss Walb.) embryos exposed to magnetic fields and in the control throughout the experiment; observations in 5 and $10 \mathrm{mT}$ fields pooled; $1-$ oxygen consumption in magnetic fields; 2 - oxygen consumption in control
No statistically significant differences in $\mathrm{O}_{2}$ consumption relative to the time of exposure to magnetic field were detected (Figs 3 and 4). However, one can notice a certain similarity between a decrease in $\mathrm{O}_{2}$ uptake rate and time of exposure in 5 and $10 \mathrm{mT}$ fields. On the other hand, for longer periods of time in 50 , 150 , and $300 \mathrm{mT}$ treatments both pooled and analysed separately, a slightly accelerated $\mathrm{O}_{2}$ uptake with time of exposure could be observed. All the differences were, however, slight and not significant.

$\mathrm{CO}_{2}$ release

No significant differences in $\mathrm{CO}_{2}$ release could be detected both with respect to embryonic developmental stages and field inductances (Table 3). An exception is provided by the difference between mean releases within 160-200 $\mathrm{D}^{\circ}$ for those embryos exposed to $5 \mathrm{mT}$ field $(0.00070$ and $0.00049 \mathrm{ml} \mathrm{CO} /$ h/embryo in treatment and control, respectively; $p=0.044$ ). A slight (statistically non-significant) increase in the amount of $\mathrm{CO}_{2}$ released in the magnetic field relative to the control was recorded within $60-80 \mathrm{D}^{\circ}$ in the $5 \mathrm{mT}$ field and within 60-80 
and $160-200 \mathrm{D}^{\circ}$ in the $10 \mathrm{mT}$ one. The amount of $\mathrm{CO}_{2}$ released did not changed significantly throughout a single test. Changes in the amount of $\mathrm{CO}_{2}$ released in the magnetic field during the embryonic development were similar to the changes in the amount of $\mathrm{O}_{2}$ taken up by an embryo exposed to a magnetic field. This is particularly well visible within $160-200 \mathrm{D}^{\circ}$ in the $5 \mathrm{mT}$ field when the amount of $\mathrm{O}_{2}$ consumed increased relative to the control and the amount of $\mathrm{CO}_{2}$ released increased significantly as well. Such similarities were observed to occur also, to some extent, in the $5 \mathrm{mT}$ field within $60-80$ and $110-130 \mathrm{D}^{\circ}$ and in the $10 \mathrm{mT}$ field within $60-80 \mathrm{D}^{\circ}$.

Respiratory quotient

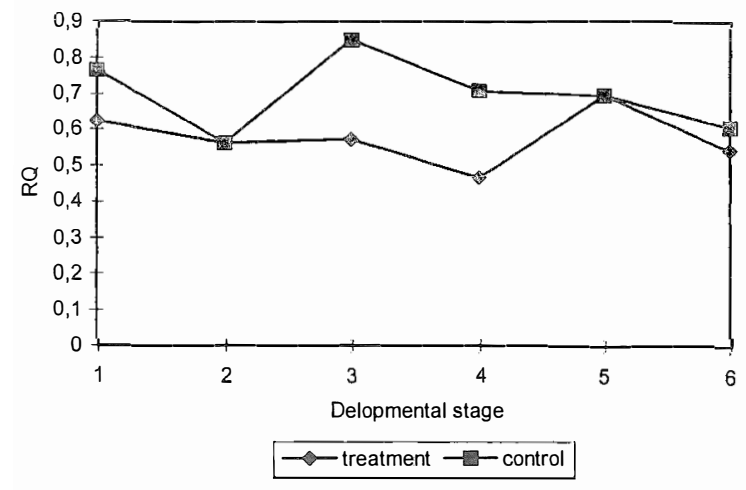

Fig. 5. Respiratory quotients of embryos exposed to 5 and $10 \mathrm{mT}$ fields (pooled observations) and in the control

Oxygen uptake and carbon dioxide release was measured simultaneously in the 5 and $10 \mathrm{mT}$ treatments. The results allowed to calculate the respiratory quotient (RQ). Fig. 5 shows pooled RQ values obtained for embryos exposed to both magnetic fields and the control. Generally, RQ values were higher in the control, but no statistical significance of the differences could be detected. The lowest and highest treatment $R Q$ values in the magnetic field were 0.47 and 0.7 , respectively; the respective control values were 0.56 and 0.8 .

\section{DISCUSSION}

The experiment described in this paper was aimed at addressing a question if, and to what extent, a magnetic field affected embryonic respiration. The answer was sought by comparing the amounts of $\mathrm{O}_{2}$ consumed and $\mathrm{CO}_{2}$ released by embryos exposed to artificial magnetic fields and the natural one. The physiological background of magnetic field effects on respiration was investigated as well.

To elucidate the questions addressed, it was necessary to review a number of phenomena, observed in experimental studies involving exposure to magnetic fields, which could affect $\mathrm{O}_{2}$ uptake of embryos. With respect to constant magnetic field effects on early embryonic development of salmonids, it could be assumed that magnetic field particularly affects those embryos the development of 
which undergoes some critical phases. The critical phases during which the embryo is particularly sensitive to external stimuli involve intensive metabolism, related to different stages of cellular division and organogenesis. Studies reported by Trifonova and Popov (1937) on $\mathrm{O}_{2}$ deficiency effects and those by Privolnev and Razumovskij (1939) involving temperature changes allowed to distinguish three critical phases: the onset of cleavage; beginning of gastrulation; and differentiation of an embryo.

Studies on incubation of fertilised eggs of trout (Salmo trutta L.), rainbow trout (O. mykiss Walb.), and Danube salmon (Hucho hucho L.) exposed to magnetic field demonstrated, too, the presence of periods of increased embryo's sensitivity to magnetic field. The embryos proved particularly sensitive to magnetic field effects immediately after fertilisation (cleavage and gastrulation) (Formicki and Winnicki 1982). The periods of increased sensitivity of the embryo to magnetic field effects seem to partially overlap the so-called critical phases distinguished by other workers.

Experiments involving magnetic field effects on embryonic respiration were started at $60 \mathrm{D}^{\circ}$, i.e., at the morula stage. Differences in $\mathrm{O}_{2}$ consumption between embryos exposed to a field and the control were found to involve eggs from the autumn spawning (exposure to 5 and $10 \mathrm{mT}$ fields). In the $50 \mathrm{mT}$ field, too (the spring spawning eggs), the period of increased sensitivity coincided with the morula stage. An increased sensitivity to magnetic field effects in the 150 and 300 $\mathrm{mT}$ fields, manifested as an increased $\mathrm{O}_{2}$ uptake was recorded within $90-100 \mathrm{D}^{\circ}$. The evident similarity of responses to magnetic field effects was observed also during organogenesis and during the circulatory system formation in the embryos $\left(140-200 \mathrm{D}^{\circ}\right)$. The intensified sensitivity was in that case manifested not only as an increase, but also - in two treatments (50 and $150 \mathrm{mT}$ fields) —as a reduced $\mathrm{O}_{2}$ consumption in the magnetic field, relative to the control.

Earlier experiments demonstrated clear effects of magnetic fields on motoric activity of the cardiac muscle and pectoral fins. Application of a magnetic field was shown to produce a change in cardiac contraction rhythm (Winnicki and Formicki 1990) and to affect movements of the pectoral fins (Winnicki et al. 1993). An increase in oxygen demand could be explained by the increased heart beat rate. It should be borne in mind, however, that the increased $\mathrm{O}_{2}$ consumption at the beginning of an experiment results most probably from increased response to magnetic stimulation at the moment the field is being applied. After this initial period, the oxygen consumption decreases somewhat to stabilise at a level higher than that of the control. Thus an increase in the cardiac muscle activity rate (reverting, after several minutes, to the initial state, the one before the field was applied) may be one, but not the only, factor resulting in the increased $\mathrm{O}_{2}$ uptake. 
Magnetic field affects various levels of organisation and structure of systems studied, which makes it difficult to single out a mechanism responsible for the increased oxygen consumption. At the cellular level, magnetic field effects on biological membranes may provide an explanation for the increased oxygen uptake in the magnetic field and for different responses of an organism at various developmental stages. Some layers of the cellular membrane display liquid crystal properties. Application of a magnetic field results in a change in the state of liquid crystals, which alters their permeability. Moreover, particles penetrating the membranes are electrically charged. Thus the magnetic field affects not only the membrane permeability, but also the electric charges actively transported across the membranes (Wadas 1978). Changes in transport of particles or atoms across biological membranes may result in acceleration or slow-down of cellular or organismic metabolism (Rosen 1993; Tenforde 1993). Such effects would be particularly pronounced during periods of intensified metabolic activity, that is during the critical phases.

On the other hand, Nossol et al. (1993) focused on low density magnetic field interacting with enzymes which catalyse cellular biochemical reactions. Operation and efficiency of intracellular metabolic pathways depend on numerous consecutive enzymatic processes. For this reason, even a weak stimulation affecting one of the initial links may substantially affect subsequent biochemical reactions (Karlson 1971). A $300 \mu \mathrm{T}$ constant magnetic field activates cytochrome oxydase. The enzyme is responsible for electron transport to particulate oxygen. An increased activity of the enzyme can be explained by magnetic field effects on either the enzyme's structure or on protons or electrons participating in the reaction (Nossol et al. 1993). On the other hand, magnetic field effects on enzymes seem to be selective, which means that not all the enzymes respond to the field and the response in those that do respond is not uniform (Haberditzl 1967). The magnetic field effects on enzymatic activity may explain the absence of significant differences between $\mathrm{CO}_{2}$ release by treatment and control embryos.

It seems, however, that the following mechanism would be most consistent with the results obtained. Application of a magnetic field reduces permeability of membranes in capillaries and respiratory epithelium of fish larvae. Consequently, at the moment of field application and for some time after it, oxygen diffusion rate slows down and the amount of oxygen taken up decreases. During this time, the larval body passes through an oxygen debt phase during which the cells use up a normal amount of oxygen, but oxygen content in the arterial blood decreases (anactic hypoxia). The larva obtains the necessary energy anaerobically from chemical substances in the body (Szabuniewicz 1964; Depeche and Billard 1994). As in other aquatic organisms, such a state cannot be prolonged in a fish larva because it can lead to asphyxia. Hence the observed compensatory reaction observed, 
involving acceleration of the heart beat rate to increase blood circulation. After a moment, another compensatory mechanism is turned on and visible as intensified fin motility, whereby oxygenated water is fed into the larval breathing system (Winnicki and Formicki 1990; Formicki and Winnicki 1996).

A magnetic field can produce stress; an embryo faces then a necessity to adapt to changed environmental conditions. Undergoing an adaptation, the embryo has to make up for its oxygen demand which is higher than that in the control. Those phenomena occur, however, during minute-long periods of time and do not explain the fact that the embryos placed in a magnetic field for prolonged periods of time, at different developmental stages, take up more oxygen than the control ones, while the magnetic field applied throughout the embryonic period extends incubation, which most likely slows down biochemical processes (Formicki, 1991). It would thus seem that the oxygen demand in a magnetic field should be lower, while the reverse is in fact true. It seems that the paradox can be explained by progressive, hyperbiotic processes involving growth and differentiation of cells. Studies on in vitro tissue cultures showed that embryonic cells grew faster than adult cells due to cellular growth activators. One can assume that the factors stimulating cellular growth are substantially activated in a magnetic field. This is evidenced by a a higher weight of hatching embryos (Formicki and Winnicki 1982; Formicki 1991) and by the higher oxygen demand of growing cells and tissues. Kholodov et al. (1996) found increased biological oxidation in the brain as a response to application of a magnetic field. The in vitro studies of McDonald (1993) demonstrated constant magnetic field to have stimulated growth of cells isolated from neonatal rats. Zhang et al. (1993), when studying domestic hen embryos, found a relationship between alternated magnetic field effects, increased $\mathrm{O}_{2}$ consumption, and faster growth.

In the present study, apart from the $\mathrm{O}_{2}$ uptake, the $\mathrm{CO}_{2}$ release was measured in the treatments involving 5 and $10 \mathrm{mT}$ fields. The results showed a slight increase in the amount of $\mathrm{CO}_{2}$ released in the magnetic field, relative to the control. The oxygen consumption by developing embryos has been rather extensively treated in the literature, while much fewer studies dealt with $\mathrm{CO}_{2}$ release (Winnicki 1967). In her experiments with carp embryos, Kamler (1976) found proteins and lipids to be the major sources of the energy expended, the contributions of both types of substances being similar and amounting to 50 and $49 \%$, respectively. The RQ values around 0.7, arrived at by Winnicki (1963) for the rainbow trout, point to lipids as the major energy source for the developing embryos of the species. In the present work, too, the RQ values were close to 0.7 , while the magnetic field-affected embryos showed lower RQ values.

The data obtained during the experiment reported here suggest that magnetic field affects oxygen consumption much stronger than it does the $\mathrm{CO}_{2}$ release. No- 
teworthy is a reference to the RQ values mentioned. Should the increase in the $\mathrm{O}_{2}$ uptake be identical with the amount of $\mathrm{CO}_{2}$ release, the treatment and control RQ values would be identical. As seen in Fig. 5, the treatment value was in fact lower. Further studies are needed to explain if the mechanism responsible involves selective effects of magnetic field on intracellular metabolic pathways, on substrates of katabolic processes, or altered $\mathrm{CO}_{2}$ evacuation across shell membranes.

\section{CONCLUSION}

1. A constant magnetic field stimulates respiration of rainbow trout embryos, as evidenced by the statistically significant increase in the oxygen uptake.

2. Respiratory stimulation in magnetic field is not uniform throughout the embryonic development and is particularly pronounced during periods of intensified morphogenesis: gastrulation and blastopore closure, organogenesis, and formation and development of circulatory system.

3. Rainbow trout embryos respond to magnetic field by increasing their oxygen uptake at the moment of magnetic field application. The altered level of oxygen demand does not change significantly with time throughout the experiment.

4. At the final stage of incubation (prior to hatching), the magnetic field of inductance values used $(5,10,50,150$, and $300 \mathrm{mT})$ did not produce any significant increase in the embryonic oxygen consumption.

5. Application of 5 and $10 \mathrm{mT}$ magnetic fields resulted in a slightly higher carbon dioxide release (at an increased amount of oxygen consumed in the magnetic field), so that the respiratory quotient in those embryos exposed to the fields was slightly lower than that in the control.

\section{ACKNOWLEDGEMENT}

The study was financially supported by the Agicultural University's grant No. BW/DRY/067/95 and partly through the State Committee for Scientific Research grant No. PO6 D 00209. 


\section{REFERENCES}

Blamk M. (ed.), 1993: Electricity and Magnetism in Biology and Medicine. San Francisco Press Inc., San Francisco.

$\mathbb{D e p e c h e ~ J o , ~ R . ~ B i l l a r d , ~ 1 9 9 4 : ~ E m b r y o l o g y ~ i n ~ f i s h . ~ A ~ r e v i e w . ~ S o c i e t e ~ F r a n c a i s e ~ d ' I c h t y o l o g i e , ~ P a r i s . ~}$

Duchiewicz J., $\mathbb{K}$. Formicki, A. Liber, 1994: Magnetic field (0-60 Hz) generating device for embryophysiological research. Zesz. Nauk. AR w Szczecinie. Ser. Rybactwo Morskie i Technologia Żywności, 164 (21): 5-9.

Formicki $\mathbb{K}$., 1991: Wpływ stałego pola magnetycznego na wczesne stadia ontogenezy ryb łososiowatych na tle podstawowych osiągnięć nauki w zakresie wpływu tych pól na organizmy żywe [Effects of constant magnetic field on early developmental stages of salmonids against the background of scientific advances in studies on effects of those fields on living organisms]. Zesz. Nauk. AR w Szczecinie, ser. Rozprawy 131: 1-119. (In Polish).

Formicki $\mathbb{K}$., 1992: Respiratory movements of trout (Salmo trutta L.) larvae during exposure to magnetic field. Acta Ichth. Piscat., 22, 2: 149-154.

Formicki $\mathbb{K}_{\text {。, }}$ A. Wimmicki, 1982: Wstępne wyniki badań nad wpływem pola magnetycznego na rozwój zarodkowy troci (Salmo trutta L.) i pstrąga tęczowego (Salmo gairdneri Rich.) [Preliminary studies on the effect of magnetic field on embryonic development of Salmo trutta L. and Salmo gairdneri Rich.]. Przegl. Zool., 26, 3-4: 417-424.

Formicki $\mathbb{K}_{\text {. }}$ A. Winnicki, 1996: Effects of constant magnetic field on cardiac muscle activity in fish embryos. Publ. Espec. Inst., Esp. Oceanogr., 21: 287-292.

H-Haberditzll W., 1967: Enzyme activity in high magnetic field. Nature, 213: 72-73.

HIermanowicz W., W. Dożańska, J. Dojlido, B. Koziorowski, 1976: Fizyczno-chemiczne badanie wody i ścieków [Physical and chemical methods of water and wastewater analysis]. Arkady, Warszawa: 361-365. (In Polish).

$\mathbb{K a m l e r} \mathbb{E}_{\text {。 }}$ 1976: Variability of respiration and body composition during early development stages of carp. Pol. Arch. Hydrobiol., 23: 431-485.

$\mathbb{K a r l s o n} \mathbb{P}$., 1971: Zarys biochemii [Fundamentals of biochemistry]. PWN, Warszawa. (In Polish).

$\mathbb{K}$ linolodov Ju. A., M. M. Alexandrovskaja, S. N. Lukjamowa, N. S. Udarova, 1969: Investigations of the reactions of mammalian brain to static magnetic fields. In: Biological Effects of Magnetic Fields, vol. 2, Plenum Press, New York: 215-234.

Klinkhardt $\mathbb{M}$. $\mathbb{B}$. A. A. Straganov, $\mathbb{D}$. A. Pavlov, 1987: Motoricity of Atlantic salmon embryos (Salmo salar L.) at different temperatures. Aquaculture, 64: 219-236.

McDonald $\mathbb{F}$. 1993: Effect of static magnetic field on osteoblasts and fibroblasts in vitro. Bioelectromagnetics, 14 : 187-196.

Nossol $\mathbb{B} ., G_{0}$ B Buse, J. Silny, 1993: Influence of weak static and $50 \mathrm{~Hz}$ magnetic fields on the redox activity of cytochrome C oxidase. Bioelectromagnetics, 14 : 361-372.

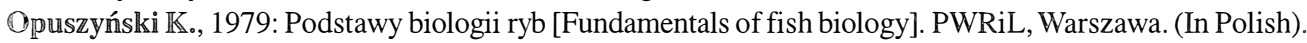

Pattee $\mathbb{E}_{\text {o, }}$ 1962: Methodes de mesure metabolisme respiratorie chez les animaux aquatiques. Hydrobiologia, Acta Hydrobiol. Hydrograph. Protistol., 19, 1: 40-56.

Privolnev T. I., A. M. Razumovskij, 1939: Vlianie ponižennoj temperatury na raznyje stadii razvitia lešč (Abramis brama). Dokl. AN SSSR, N.s., 23.

Rosen A.D., 1993: Membrane response to static magnetic field: Effect of exposure duration. Biochem. Biophys. Acta, 1148: 317-320.

Szabuniewicz $\mathbb{B}$., 1964: Zarys fizjologii człowieka [Fundamentals of human physiology]. PZWL, Warszawa. (In Polish).

Tenforde T. S., 1979: Magnetic field effects on biological systems. Plenum Press, New York.

Tenforde T. So, 1993: Cellular and molecular pathways of extremely low frequency electromagnetic field interactions with living systems. In: Electricity and Magnetism in Biology and Medicine (Blank M., ed.). San Francisco Press, San Francisco: 1-8. 
Trifonova A. N., N. A. Popov, 1937: Razvitie i dychanije ikry ryb pri razliãnom parcialnom davlenii kisloroda. Razvitie ikry lososia i okunia pri ponižennom parcialnom davlenii kisloroda [Development and respiration of fish eggs in different partial pressure of oxygen. Development of salmon and perch eggs in lowered partial pressure of oxygen]. Učen. Zap. LGU, 15.

Vernier J. M., 1967: Table chronologique du developpment embryonnaire de la truite arc-en-ciel, Salmo gairdneri Rich. 1836. Ann d'Embryol Morph., 2, 4: 495-520.

Wadas R., 1978: Biomagnetyzm [Biomagnetism]. PWN, Warszawa. (In Polish).

Winnicki A., 1963: Przemiana oddechowa zarodków Salmo trutta (L.) i Salmo irideus (Gibb.) w środowiskach o różnych możliwościach transportu gazów [Respiratory transformation in embryos of Salmo trutta (L.) and Salmo irideus (Gibb.) in habitats differing in their gas transport properties]. PhDThesis, Wyższa Szkoła Rolnicza w Olsztynie, Olsztyn. (In Polish).

Winnicki A., 1967: Embryonic development and growth of Salmo trutta L. and Salmo gairdneri Rich. in conditions unfavorable to respiration. Zool. Pol., 17, $1: 45-58$.

Winnicki A., K. Formicki, 1990: Effect of constant magnetic field on myocardum activity in larvae of trout (Salmo trutta L.). Bull. Pol. Acad. Sci. Biol., 38: 57-60.

Winnicki A., K. Formicki, A. Korzelecka, A. Sobociński, 1993: Cardiac responses of pike (Esox lucius L.) embryos and larvae to constant magnetic field. Arch. Ryb. Pol., 1, 2: 87-93.

Zhang Q., F. L. Tabrah, G. C. Whittow, 1993: Effects of 60-Hz sinusoidal electromagnetic field on avian embryonic growth and oxygen consumption. Electro- and Magnetobiol., 12(1): 27-37.

\section{Tomasz PERKOWSKI, Krzysztof FORMICKI}

\section{WPŁYW STAEYCH PÓL MAGNETYCZNYCH NA ODDYCHANIE ZARODKÓW PSTRĄGA TĘCZOWEGO (ONCORHYNCHUS MYKISS WALB.)}

\section{STRESZCZENIE}

Badano ilość pobieranego tlenu i wydalanego dwutlenku węgla przez zarodki pstrąga tęczowego (Oncorhynchus mykiss Walb.) poddane działaniu stałego pola magnetycznego o wartości 5 i $10 \mathrm{mT}$ (tlen i dwutlenek węgla) oraz 50, 150 i $300 \mathrm{mT}$ (tlen) i porównywano wyniki uzyskane $\mathrm{z}$ wynikami zarejestrowanymi u zarodków rozwijających się w warunkach naturalnego pola geomagnetycznego (kontrola).

Stwierdzono, że pole magnetyczne stymuluje procesy oddechowe u zarodków pstrąga tęczowego, czego wyrazem jest istotny wzrost zużycia tlenu, szczególnie większy w okresach wzmożonej morfogenezy.

Pole magnetyczne (5 i $10 \mathrm{mT})$ powoduje nieznacznie większe wydalanie dwutlenku węgla, przy wzroście ilości zużywanego tlenu. Współczynnik oddechowy zarodków poddanych działaniu pola jest nieco wyższy od współczynnika oddechowego zarodków w kontroli.

Authors' address

Tomasz Perkowski PhD

Krzysztof Formicki PhD DSc

Department of Fish Anatomy and Embryology

Agricultural University of Szczecin

Kazimierza Królewicza 4, 71-550 Szczecin, Poland 